\title{
Draft Genome Resources of Two Strains of Xylella fastidiosa XYL1732/17 and XYL2055/17 Isolated from Mallorca Vineyards
}

\author{
Margarita Gomila, ${ }^{1, \dagger}$ Eduardo Moralejo, ${ }^{2}$ Antonio Busquets, ${ }^{1}$ Guillem Segui, ${ }^{1}$ Diego Olmo, ${ }^{3}$ Alicia \\ Nieto, ${ }^{3}$ Andreu Juan, ${ }^{4}$ and Jorge Lalucat ${ }^{1}$ \\ ${ }^{1}$ Microbiology (Biology Department), University of the Balearic Islands, 07122 Palma de Mallorca, Spain \\ ${ }^{2}$ Tragsa, Empresa de Transformación Agraria, Delegación de Baleares, 07005 Palma de Mallorca, Spain \\ ${ }^{3}$ Serveis de Millora Agrària, Govern Balear, 07009, Palma de Mallorca, Spain \\ ${ }^{4}$ Servicio de Agricultura, Conselleria de Medi Ambient, Agricultura i Pesca, 07006 Palma de Mallorca, Spain
}

\begin{abstract}
Xylella fastidiosa is a plant-pathogenic bacterium that causes serious diseases in many crops of economic importance and is a quarantine organism in the European Union. This study reports a de novo-assembled draft genome sequence of the first isolates causing Pierce's disease in Europe: X. fastidiosa subsp. fastidiosa strains XYL1732/17 and XYL2055/17. Both strains were isolated from grapevines (Vitis vinifera) showing Pierce's disease symptoms at two different locations in Mallorca, Spain. The XYL1732/17 genome is 2,444,109 bp long, with a $\mathrm{G}+\mathrm{C}$ content of $51.5 \%$; it contains 2,359 open reading frames and 48 tRNA genes. The XYL2055/17 genome is $2,456,780$ bp long, with a $\mathrm{G}+\mathrm{C}$ content of $51.5 \%$; it contains 2,384 open reading frames and 48 tRNA genes.
\end{abstract}

Xylella fastidiosa is a Gram-negative bacterium considered a quarantine organism in the European Union that causes diseases in many economically important crops such as almond, grape, olive, cherry, citrus, elm, and coffee trees as well as in many ornamental plants (Sicard et al. 2018). It is a phytopathogenic, xylem-limited, and nutritionally fastidious bacterium. Since the detection of the bacterium in the Apulia region of Italy (2013), where it is associated to a severe epidemic on olive trees producing the olive quick decline syndrome, the pathogen has also been detected in several other plant species in France (2015) and on one potted plant (Nerium oleander) in a greenhouse in Germany (2016) (EPPO 2016). During official surveys in autumn 2016 in Mallorca Island (Spain), X. fastidiosa was detected in cherry trees and Polygala myrtifolia plants located in a garden center near the locality of Manacor (Mallorca, Balearic Islands). More exhaustive surveys demonstrated widespread distribution of the bacterium in the Balearic Islands, and the detection of three $X$. fastidiosa subspecies ( $X$. fastidiosa subsp. fastidiosa, subsp. multiplex, and subsp. pauca). Recently $X$. fastidiosa has been also detected in the mainland of Spain in Alicante, Madrid, and Andalucia (2017). Sequencing the genomes of strains of this species isolated from different geographical regions will advance our understanding of the genomic mechanisms underlying host adaptation, increase our knowledge of molecular mechanisms of plant pathogenicity, and will be useful in epidemiological studies.

Strains XYL1732/17 and XYL2055/17 of $X$. fastidiosa were isolated in July and August of 2017, respectively, from leaves of two grapevines showing typical Pierce's disease symptoms at two different vineyards of Manacor (Mallorca), following the EPPO recommendations for isolation (EPPO 2016). The strain XYL2055/17 was isolated from the white grape cultivar Parellada. Strain XYL1732/17 was isolated from an unknown cultivar. Strains were cultured on periwinkle wilt (PWG) medium at $28^{\circ} \mathrm{C}$ for 14 days, and triple cloned before being stored on $\mathrm{PW}$ broth containing $20 \%$ glycerol at $-80^{\circ} \mathrm{C}$. Bacterial cells were collected from agar plates, washed

${ }^{\dagger}$ Corresponding author: M. Gomila; E-mail: marga.gomila@uib.es

\section{Funding}

This work was supported by funds from the Obra Social "La Caixa", by the Direcció General d'Innovació i Recerca (Comunitat autònoma de les Illes Balears) through the project "AAEE024/ 2017" (Co-funded by European Regional Development Fund/European Social Fund "Investing in your future"), as well as from the project E-RTA2017-00004-C06-04 (Desarrollo de estrategias de erradicación, contención y control de Xylella fastidiosa en España: Diagnóstico, estructura genética y gama de huéspedes from Programa Estatal de I+D Orientada a los Retos de la Sociedad) from the Spanish Government and the Spanish State Research Agency. 
with $1 \mathrm{ml}$ of Ringer solution, and centrifuged at $16,000 \times g$ for $5 \mathrm{~min}$. Total genomic DNA was extracted from the pelleted cells by using the Wizard genomic DNA purification kit (Promega, Fitchburg, WI) following manufacturer recommendations. Sequence analysis of the amplicon of the sigma 70 factor (Minsavage et al. 1994) and the seven housekeeping genes defined by Yuan et al. (2010) allowed the identification of both isolates as $X$. fastidiosa subsp. fastidiosa and were assigned to the sequence type ST1.

Whole-genome shotgun sequence of both strains were performed on the Illumina MiSeq platform (Illumina, Inc., San Diego, CA) with 300-bp paired-end reads. Illumina sequence yielded 1,398,568 and 1,998,276 reads for strains XYL1732/17 and XYL2055/17, respectively. The Newbler Assembler version 2.9 software package (Roche) was used for de novo genome assembly. The draft genome size was 2,456,780 and 2,444,109 bp for XYL1732/17 and XYL2055/17, respectively. The XYL1732/17 genome was assembled in 135 contigs, with an N50 of a $61,120 \mathrm{bp}$, an average length of $18,104 \mathrm{bp}$ being the largest one of 296,048 bp and a median genome coverage depth of 102-fold. The genome of strain XYL2055/17 was assembled in 135 contigs, with an N50 of a $63,571 \mathrm{bp}$, an average length of $18,198 \mathrm{bp}$ being the largest one of $216,332 \mathrm{bp}$ and a median genome coverage depth of 151 -fold. $\mathrm{G}+\mathrm{C}$ content of both genomes was $51.5 \%$. Genomes were deposited in GenBank under the accession numbers QTJT00000000 (XYL1732/17) and QTJS00000000 (XYL2055/17).

Gene prediction and annotation were performed using the NCBI Prokaryotic Genome Annotation Pipeline (https://www.ncbi.nlm.nih.gov/genome/annotation_prok). Analysis and comparison of the functional annotation were done using the KEGG automatic annotation server (Moriya et al. 2007). Contig 51 and contig 46 for strains XYL1732/17 and XYL2055/17, respectively, contain a complete rRNA operon. Forty-nine tRNA genes (48 tRNA genes) were detected in both strains, and 2,304 and 2,329 protein coding genes were annotated in XYL1732/ 17 and XYL2055/17, respectively. Around $25 \%$ of the genes annotated belonged to hypothetical proteins. Both genomes possessed genes related with type IV pili synthesis and fimbrial proteins that play an important role in twitching motility, biofilm formation, and cell-cell aggregation ( $\mathrm{Li}$ et al. 2007). Several genes responsible for the transport of biopolymers were also found, as well as type II secretion system (T2SS) genes used to secrete proteins into the extracellular milieu and/or host organisms (diverse array of toxins, degradative enzymes, and other effectors) (Cianciotto and White 2017). Sixteen genes related to protein transport across membranes were associated to a sec dependent pathway, to a toxin-antitoxin (TAT) system and to a signal peptidase.

Mobile genetic elements were also found, some integrases and transposases as well as phage elements. Plasmid genes related to replication, mobilization, and conjugative transfer were predicted and annotated. The presence of plasmid sequences was checked manually and using plasmidSPAdes algorithm and software (Antipov et al. 2016). Plasmid genes were found in strain XYL2055/17 in contigs 30, 39, 68, and 113: in strain XYL1732/17 the plasmid genes were located in contigs $35,42,75,100$, and 120. A BLASTN search demonstrated the highest sequence similarities with the conjugative plasmids pXFAS01 (CP001012) and pXFAS_5235 (QWLC01), which were reported in X. fastidiosa strain M23 (Chen et al. 2010) and in $X$. fastidiosa subsp. fastidiosa strain IVIA 5235 (Landa et al. 2018), respectively. The plasmid synteny was also confirmed by recruiting the reads against the plasmid sequences using the CLC Genomics Workbench (CLC Bio, Aarhus, Denmark), yielding a single circular plasmid sequence of 38,297 nucleotides. The plasmid contained at least 40 annotated genes, including a cluster of conjugal transfer proteins (tra genes) containing all genes necessary for conjugation transfer to occur. Comparative analyses showed a conserved organization with other conjugative plasmids, although further analysis to elucidate the complete plasmid sequence was not performed. Both genomes also contained genes of a TAT system class with functional roles in plasmid inheritance and maintenance, cell development and environmental stress response (relE/ParE, HicB, and YafQ family toxins) (Wen et al. 2014), and repeats-in-toxin (RTX) exoproteins organized in four loci with a complex repetitive structure sequence. These systems have been shown to play a major role in virulence of a broad range of Gram-negative pathogens (Gambetta et al. 2018). This de novo genome assemblies provide baseline information for further studies on the pathogenicity determinants of these strains.

To evaluate the subspecies status of both strains the average nucleotide identities based on BLAST (ANIb values) were calculated with the available whole-genome sequences of $X$. fastidiosa in GenBank, including $X$. fastidiosa subsp. fastidiosa, $X$. fastidiosa subsp. multiplex, and $X$. fastidiosa subsp. pauca (Richter et al. 2015). In all cases, strains XYL1732/17 and XYL2055/17 clustered with members $X$. fastidiosa subsp. fastidiosa, confirming their multilocus 
Table 1. ANIb values of strains XYL1732/17 and XYL2055/17 with their closest related strains of Xylella species

\begin{tabular}{|c|c|c|}
\hline $\begin{array}{l}\text { Strains }^{\mathrm{a}} \\
\text { XYL1732/17 (QTJT01) }\end{array}$ & $\begin{array}{c}\text { XYL1732/17 } \\
100.00\end{array}$ & $\begin{array}{c}\text { XYL2055/17 } \\
99.96\end{array}$ \\
\hline $\begin{array}{l}\text { XYL2055/17 (QTJS01) } \\
\text { X. fastidiosa M23 (CP001011) } \\
\text { X. fastidiosa subsp. fastidiosa IVIA } 5235 \text { (QWLC01) } \\
\text { X. fastidiosa Temecula1 (AE009442) } \\
\text { X. fastidiosa subsp. fastidiosa ATCC } 35879^{\top} \text { (JQAP01) } \\
\text { X. fastidiosa subsp. sandyi Ann-1 (CP006696) } \\
\text { X. fastidiosa subsp. multiplex ATCC } 35871^{\top} \text { (AUAJ01) } \\
\text { X. fastidiosa CoDiRO (JUJW01) } \\
\text { X. fastidiosa subsp. pauca De Donno (CP200870) } \\
\text { X. taiwanensis PLS229 }{ }^{\top} \text { (JDSQ01) }\end{array}$ & $\begin{array}{l}99.96 \\
99.92 \\
99.90 \\
99.88 \\
99.75 \\
97.95 \\
97.68 \\
95.97 \\
95.91 \\
83.18\end{array}$ & $\begin{array}{r}100.00 \\
99.94 \\
99.93 \\
99.88 \\
99.75 \\
97.95 \\
97.66 \\
95.91 \\
95.86 \\
83.18\end{array}$ \\
\hline
\end{tabular}

a Accession numbers for each genome are indicated in parentheses.

sequence typing assignation. ANIb values of our strains against closest-related strains of Xylella species are indicated in Table 1. Genomic comparisons between both strains showed a $99.96 \%$ similarity, although they were not identical. A more exhaustive analysis should be done comparing both strains.

The genomic resource reported here expands our knowledge of $X$. fastidiosa in the origin of European outbreaks and will make possible to conduct comparative genomic studies to better understand the evolution and the epidemiology of this pathogenic bacteria in Europe.

Accession numbers. The raw reads from this study have been submitted to the NCBI Sequence Read Archive (SRA) under accession numbers SRR8082354 (XYL1732/17) and SRR8080709 (XYL2055/17). This whole-genome shotgun project has been deposited in DDBJ/ EMBL/GenBank under accession numbers QTJT00000000 (XYL1732/17) and QTJS00000000 (XYL2055/17). The versions described in this paper are the first version, QTJT01000000 and QTJS01000000, respectively.

\section{Literature Cited}

Antipov, D., Hartwick, N., Shen, M., Raiko, M., Lapidus, A., and Pevzner, P. A. 2016. plasmidSPAdes: assembling plasmids from whole genome sequencing data. Bioinformatics 32:3380-3387.

Chen, J., Xie, G., Han, S., Chertkov, O., Sims, D., and Civerolo, E. L. 2010. Whole genome sequences of two Xylella fastidiosa strains (M12 and M23) causing almond leaf scorch disease in California. J. Bacteriol. 192:4534.

Cianciotto, N. P., and White, R. C. 2017. Expanding role of Type II secretion in bacterial pathogenesis and beyond. Infect. Immun. 85:e00014-e00017.

EPPO. 2016. Diagnostic protocols for regulated pests: PM 7/24 (2) Xylella fastidiosa. OEPP/EPPO Bull. 46:463-500.

Gambetta, G. A., Matthews, M. A., and Syvanen, M. 2018. The Xylella fastidiosa RTX operons: Evidence for the evolution of protein mosaics through novel genetic exchanges. BMC Genomics 19:329.

Landa, B. B., Velasco-Amo, M. P., Marco-Noales, E., Olmo, D., López, M. M., Navarro, I., Monterde, A., Barbé, S., Montes-Borrego, M., Román-Écija, M., Saponari, M., and Giampetruzzi, A. 2018. Draft genome sequence of Xylella fastidiosa subsp. fastidiosa strain IVIA5235, isolated from Prunus avium in Mallorca Island, Spain. Microbiol. Resour. Announcements 7: e01222-e18.
Li, Y., Hao, G., Galvani, C. D., Meng, Y., De La Fuente, L., Hoch, H. C., and Burr, T. J. 2007. Type I and type IV pili of Xylella fastidiosa affect twitching motility, biofilm formation and cell-cell aggregation. Microbiology 153:719-726.

Minsavage, G. V., Thompson, C. M., Hopkins, D. L., Leite, R. M. V. B. C., and Stall, R. E. 1994. Development of a polymerase chain reaction protocol for detection of Xylella fastidiosa in plant tissue. Phytopathology 84:456-461.

Moriya, Y., Itoh, M., Okuda, S., Yoshizawa, A. C., and Kanehisa, M. 2007. KAAS: An automatic genome annotation and pathway reconstruction server. Nucleic Acids Res. 35:W182-W185.

Richter, M., Rosselló-Móra, R., Glöckner, F. O., and Peplies, J. 2015. JSpeciesWS: A web server for prokaryotic species circumscription based on pairwise genome comparison. Bioinformatics 32:929-931.

Sicard, A., Zeilinger, A. R., Vanhove, M., Schartel, T. E., Beal, D. J., Daugherty, M. P., and Almeida, R. P. P. 2018. Xylella fastidiosa: Insights into an emerging plant pathogen. Annu. Rev. Phytopathol. 56:181-202.

Wen, Y., Behiels, E., and Devreese, B. 2014. Toxin-antitoxin systems: Their role in persistence, biofilm formation, and pathogenicity. Pathog. Dis. 70:240-249.

Yuan, X., Morano, L., Bromley, R., Spring-Pearson, S., Stouthamer, R., and Nunney, L. 2010. Multilocus sequence typing of Xylella fastidiosa causing Pierce's disease and oleander leaf scorch in the United States. Phytopathology 100:601-611. 